\title{
The Challenges of Adapting the Syntactic Constructions to the Translation of the Poems of Charles Baudelaire
}

\author{
Msc. Edona Marku \\ University of Tirana, Faculty of History and Filology, Street of Elbasani, Tirana, Albania
}

\begin{abstract}
The translation of poetry has always been a problem and is considered difficult, as it includes a number of language and extraneous factors that make it difficult. Our paper approaches to the translating process of the poetry volume "The Flowers of Evil" by Charles Baudelaire focusing on linguistic and syntactic literary translation. Studies done so far in Albania have focused mostly on the literary aspects of the poems, addressing its stylistic and artistic views. Thus, through this paper we thought to treat the language of the poems, concretely the syntactic challenges of their translation. This paper is conceived as a study of theoretical and practical character in the field of Translation Studies. Through translation theories and translation process strategies as well as grammar and syntax manuals, our study sheds light on the translation of Charles Baudelaire's "The Flowers of Evil" work by basing research and comparative analysis on the theories and views of theorists, researchers and syntaxists such as: Peter Newmark, Umberto Eco, Edmod Tupe, Émile Benveniste, André Lefevere, F. de Saussure etc.
\end{abstract}

Keywords: Challenge, translation, poetry, syntax, comparative analysis etc.

DOI: $10.7176 /$ JLLL/52-07

\section{Introduction}

This paper deals with the linguistic and comparative analysis of the dynamics of the translation of Baudelaire's poetry and in particular, the challenges of syntax adaptations from French into Albanian, which in our judgment we lose most from. The selection of this author and his poetic volume "The Flowers of Evil" has been made for several reasons. The first cause consists in the fact that Charles Baudelaire is one of the most important authors of modernism and in Albania the studies around this author and his work are minimal. The other reason relates to the issue of translation of the poetic volume taken into consideration, where during the many reviews we have encountered loss and major changes of the work not only in linguistic aspects, which is our objective but also in the styles, metric, etc. Another cause that influenced the selection of this author, is his very special language, especially the syntax of his verse, which poses a separate challenge to be translated into another language, specifically in Albanian. Our study focuses on the process of translating Baudelaire's poems, examined in linguistic and mostly syntactic aspects, as well as presenting contrasts of linguistic and syntax losses during the translation into Albanian by two different translators, based on the syntax of sentence and related matters.

\section{Methodology}

For the realization of this paper, two methods will be used:

1. Descriptive method - for the study of relevant theoretical literature.

2. Analytical-comparative method for analysis of language corpus.

Through the descriptive method we have made an analysis of literary translation mainly of translating poetry, translation tradition, translation issues and the translation problems over the years. Meanwhile, through the analytical-comparative method, the syntax of the sentence between the two languages is compared and the relevant issues in the grammar of this part. Also through this method the original text in French is compared with the Albanian variants. Based on this approach, the paper highlights the differences between the two language codes, the syntax of the two languages, as well as the differences and losses we have in the translation variants of poetry and in the construction of verses. So, we notice the challenges the translator has in the syntax constructions adaptations, as we have to abide two very different linguistic codes. By working with these two methods, our objectives will be easily achieved.

\section{A general overview of poetic translation. Historical-literary background of French poet creativity} Charles Baudelaire; the translation issue of his poetry.

\subsection{Translation of poetry - challenge for the translator}

Researcher E. Nida in his work "Towards a Science of Translation" describes translation as an extremely complex process, making it difficult to build a unitary translation theory. By making a comparison with other literary genders, the translation of poetry is considered to be the most difficult and there may be a lot of discussions about potential changes to the original. According to Aurel Plasari: "at the beginning of any remorse for a translation story, researches scholars are usually forced to distinguish between translation, adaptation and 
editing" . So the reasoning of this issue is that, it is impossible to pass all the factors and features of the original in the translation variant. The translation carries an early origin. Among the old translation proofs is the return of the Bible from ancient Hebrew to ancient Greek. Since Greek-Roman antiquity, there have been opinions on theories and issues related to translation. The art of translation, according to Horace and Cicero, is about the interpretation of the text in order to create a new version: "Non verbum de verbo, sed sensum de sensu" (not the word, but the meaning). Further, the translation has undergone changes and improvements in quality from the epoch to the present day, but essentially preserving the theories and principles of the forerunners.

Translation of poetry has been considered the most difficult and has been the subject of extensive discussion, especially in the field of literary translation. Most of the discussions consist of theoretical translation issues, where we have different views. Although it is extremely important that the features of the original text should be highlighted, another translation criterion is the preservation of the poetic values of translated text.

According to Frost, "the main feature of poetic discourse that distinguishes it from ordinary discourse is that form can not be separated from poetic content". ${ }^{3}$ Content is fundamentally related to language and that is what makes translating poetry more difficult than any other type of translation. Furthermore, Jacobson in "Linguistics and Poetics" claims that: "Poetry is untranslatable and it can only be recreated alienated". So, the translator of poetry should aim for accuracy and this makes the translator's dexterity difficult. Another researcher André Lefevere ${ }^{4}$ lists some techniques around the translation, which can be used when we translate something. We need to clarify that translating poetry does not mean that all aspects of poetry are translated into practice, because each language has its own lexical, linguistic and structural pattern that differs from another language. The interpreter should have sufficient knowledge of the syntax functions of both languages and he should know the characteristics of each language well. During the translation we have difficulty, because the syntax of each language has its own changes, the way of building sentences, words and sentence reports, etc., all carry their different features from language to language, but approximating with the original is not impossible, as we have many successful translations.

\subsection{Charles Baudelaire's poetry - translation context}

To understand the style and creative process of Charles Baudelaire, who is one of the greatest French literary writers, the social, historical and economic conditions of the country should be recognized at the time when the writer has started his literary work.

Charles Baudelaire was born in Paris on 9 April 1821 and died on 31 August, 1867. In different biographies it is noted that he had a very difficult life. During his life and passion for the Beauty, he was constantly divided into two, between ecstasy and the horror of life and of human existence. Charles Baudelaire left behind, the collection "The Flowers of Evil", which is one of the most prominent collections of French poetry.

Ch. Baudelaire is distinguished for his language, specifically for his special syntax, which makes it even more difficult to translate his work into another language. Arthur Rimbaud saw Baudelaire as an "alchemist of the word" who by its power was able to turn the "mud into gold". Baudelaire's language is original and has come as an innovation in French literature, and is a language of evocation, comparison and correspondence. His work has been translated into several languages around the world, while in Albanian we have translated only the volume "The Flowers of Evil". The aforementioned volume is one of his translated works, which also recognizes some variants. There are some different variants of the volume in the Albanian language (Mensur Raifi, Anton Papleka, Dritan Thomallari etc.), and in English, this volume recognizes about 20 variants from different translators.

Regarding the translation context of his poetry, we see that in the moments of translation she loses and changes a lot. Eco in the book, "Saying almost the same thing", presents a typical example of this case. He takes the case of poetry "Les chats" by Baudelaire, which is not translated by an automatic translator, but by a real translator, such as Mario Bonfantini. Significant variations have occurred in the content field, because, for example the word "focolare" has narrowed the semantic spectrum of the word "maison," which is wider than that of the word used by Bonfantini. So, the translator has decided that, in addition to the content of the French text, the main effect or goal to be respected was the poetic one and over there he played everything.

Refer to a poem of this author translated in Albanian (a comparison of the degree of change made by us). From the comparative analysis of Baudelaire's poem "The Albatross" and variants in the Albanian language, there is a noticeable difference between the original and the variants in Albanian. In poetry, the definition of "L'homme d'ekuipage" is a sophistication to define sailors. This used form generalizes the perpetrators of action and involves humanity.

\footnotetext{
${ }^{1}$ Plasari, A. Tetor 1990,'Letërsia dhe Muret”.Tiranë.Shkrimtari dhe Koha,Fq.189.

2 Tufa, A.Shkurt 2008,"Mistika e origjinalit",Tiranë (tezë doktorature)Fq.46.

${ }^{3}$ Frost, W. 1969. "Dryden and the Art of Translation", New Haven, CON: Yale University Press.

${ }^{4}$ Lefevere, A. (1975) "Translating poetry": Seven strategies and a blueprint.Amsterdam- Assen: Van Gorcum,fq.20

5 "The men of a crew"- is translated by W. Aggeler, 1954. "The flowers of Evil, Fresno, CA: Academy Library Guild.
} 
In Albanian language this word has not come, because this word is simply translated "sailors" into all translations, not giving the word Baudelaire's connotation in the original. In essence, this word is written by the author himself to make it comprehensible, because it could only be used "l'ekuipage", but the fact that "l'homme" preavailing makes it more general. From the comparisons made, we see that the degree of change is major at the semantic, metric, but also syntactic level due to the apparent differences between the syntax of the two languages.

\section{Approach of sentences constructions between the Albanian and French language.}

This second part of our study aims to present the syntax of the sentence of both languages, Albanian and French languages, the key issues related to the syntax, also the main differences between the languages in this aspect. The syntactic comparison helps to better understand the difficulty of translating work from French to Albanian. As stated above, we will consider the most fundamental issues of sentence constructs.

The sentence in both Albanian and French has known concepts and theories from different authors of linguistic scholars, but what is worth mentioning is the fact that these definitions in both languages do not carry any substantial changes in the content. Again, the sentence remains the fundamental unit of the syntax, which carries its grammatical and schematic side.

Every language has its own rules to list words in sentences and between the Albanian and the French as a neo-latin language there are visible differences. In Albanian grammar, the order of sentences in a period, as in a simple sentence, is relatively inexpensive: "The limbs of the sentence can be placed in different places without changing their syntax function ${ }^{1}$." Meanwhile, any concrete placement in a given sentence is conditioned by the importance they have in that sentence, by their expressive weight and emotional expression. The French language as well as the other neo-latin languages (Italian, Spanish) tends to an embedded order of words in a sentence, of the type of the subject-predicate-object. Why is this happening? Because, in languages with simplified morphology, the syntax functions are mainly determined by the position of the words in the sentence.

There are also other changes that are related to the questionnaire. Regarding the construction of the questionnaire, what constitutes the essential distinction is the fact that in the French language the question is always expressed with a verb in narrative or conditional mode and never in conjunction.

Translation difficulties are also the special constructions we encounter in the French language. French as any other language has special constructions, which we do not encounter in other languages and become evident in translation moments, when translators encounter difficulties and phrases change, or phrase elements remain untranslated.

There are some words that accompany each phrase in French, which are almost never used in Albanian. Words such as "ce / c'est and il $y$ a" are the most commonly used French phrases, which are used in all sentences and periods, as in the beginning, but in many cases even in the middle of the sentence.

\section{Comparative analysis between the original and the variants of the Albanian language.}

\subsection{Translation and the change of the subject}

When translating a piece from the original language into the other, one thing necessarily changes, such as meaning, grammar, content, stylistic, etc. These changes are primarily due to the adaptation of the languages. Languages differ from each other, especially in the grammatical and syntax aspects, which is our goal in this paper, which often because of the content of a verse, string, or phrase this can change. Below we will see how the translation of the word constitutes a change in the variants in Albanian, since the languages have differences in this aspect.

Unlike French, the order of limbs in sentences in Albanian is not generally embedded. There is a common order: subject + predicate + object + context $^{2}$. But it can change without substantially altering syntax reports, most of the time with changes in syntax and stylistic coloration. In the original version, we notice that the sentences (verses, because we are dealing with poetry), they do not have this looseness, where the sentence can begin without a subject. It requires either a subject, which can be expressed in different forms, or a sentence that starts with a subset.

Here are some examples of the original and variants in Albanian to illustrate this idea:

\footnotetext{
${ }^{1}$ Akademia e shkencave.2002, "Gjuha shqipe 2", Tiranë, f. 508.

${ }^{2}$ Akademia e shkencave të Shqipërisë,2002. Instituti i gjuhësisë dhe letërsisë.“Gramatika e gjuhës shqipe 2”, , Tiranë, f.72.
} 
Table 1. Translation and the change of the subject.

\begin{tabular}{|c|c|c|}
\hline Ch. Baudelaire & M. Raifi & D. Thomollari \\
\hline $\begin{array}{l}\text { Le lavire glissant sur less goufres } \\
\text { amers. (L'abatross", fq. 16) }\end{array}$ & $\begin{array}{l}\text { Mbi anije që sipër greminave të } \\
\text { njelmta shket.("Albatrosi" fq. 10). }\end{array}$ & $\begin{array}{l}\text { Përmes thellësive të hidhura të } \\
\text { detrave. ("Albatrosi", fq. 24) }\end{array}$ \\
\hline $\begin{array}{l}\text { Puget, mélancolique empereur des } \\
\text { forçats. ("Les phares", fq. 20) }\end{array}$ & $\begin{array}{l}\text { I dobët, Pyzhe, mbret melankolik i } \\
\text { robërve. ("Faret", fq. 14) }\end{array}$ & $\begin{array}{l}\text { Puzhe, } i \text { të detyruarve sovrani } \\
\text { melankolik. ("Fanarët", fq. 28) }\end{array}$ \\
\hline $\begin{array}{l}\text { Ma pauvre muse, hélas qu'as-tu } \\
\text { donc ce matin? ("La muse malade", } \\
\text { fq. } 21 \text { ) }\end{array}$ & $\begin{array}{l}\text { Ç'ke moj Muzë e gjorë në këtë } \\
\text { mëngjes veror? ("Muza e sëmurë", } \\
\text { fq. 16) }\end{array}$ & $\begin{array}{l}\text { Medet, muza ime e shkretë! Ky } \\
\text { mëngjes po të mundon? (“Muza e } \\
\text { sëmurë", fq. } 29\end{array}$ \\
\hline $\begin{array}{l}\text { Je respire l'odeur de ton sein } \\
\text { chaleureux, } \\
\text { Je vois se dérouler des rivales } \\
\text { heureux. ("Parfum exotique", fq. } \\
\text { 33) }\end{array}$ & $\begin{array}{l}\text { Dhe erë e gjive t'tu m'kaplon me } \\
\text { ngroht'si, } \\
\text { Më dalin para sysh brigje e } \\
\text { fatlumni. ("Erë ekzotike", fq. } 25 \text { ) }\end{array}$ & $\begin{array}{l}\text { Symbyllur, në ngrohtësinë e një } \\
\text { nate vjeshte, } \\
\text { Shoh para meje plazhe të lumtur, } \\
\text { çmendurisht të fekur. ("Parfum } \\
\text { ekzotik", fq. 41) }\end{array}$ \\
\hline
\end{tabular}

As we see in the examples above, the subject changes, or it does not translate at all, or simply the sentence starts with the relevant predicate, what makes the subject meaningful and of course for Albanian, is a regular syntax. So, the translator of poetry should aim for accuracy and this makes it very difficult the dexterity of translator expression. Significant changes can be observed even within the variants in Albanian of different authors. This proves that the translator is aiming to convey a sense of poetry, but also to give it an effect, which is also felt by the reader, and is able to make conscious changes.

\subsection{Displacement of the order of words}

The piece we are relying on is a volume of poetry, and as is well known, poetry has a special language that we can often encounter irregularly constructed syntax, for reasons of rhyme, metrics, and other effects that carries a poem. In the case of this poet and in many of his poems we have a fixed order, as defined in French grammar, an order which in the Albanian variants causes the verse to undergo changes, sometimes too profound, affecting even in itself, the meaning of the poem. The causes are clear because we have mentioned that French as a neolatin language has a fixed order and that a correct sentence must be constructed according to that established order. Whereas when that sentence behaves in another language, in our case in Albanian, there are differences and mismatches of the meanings.

Comparative table below will present these changes:

Table 2. Displacement of the order of words

\begin{tabular}{|l|l|l|}
\hline \multicolumn{1}{|c|}{ Ch. Baudelaire } & M. Raifi & \multicolumn{1}{c|}{ D. Thomollari } \\
\hline $\begin{array}{l}\text { Je vois ma femme en esprit. Son } \\
\text { regard, }\end{array}$ & $\begin{array}{l}\text { Më bëhet se e shoh gruan time. } \\
\text { Shikimi i saj si i yti është, kafshë e } \\
\text { Comme le tien, aimable béte. ("Le } \\
\text { chat", fq. 43) }\end{array}$ & $\begin{array}{l}\text { Të dashurën shoh në shpirt. } \\
\text { Shikimi i saj më ngjan, } \\
\text { Si i yti, kafshë e dashur dhe e qetë. } \\
\text { ("Macja", fq. 52) }\end{array}$ \\
\hline $\begin{array}{l}\text { Les soirs illuminés par l'ardeur du } \\
\text { charbon, }\end{array}$ & $\begin{array}{l}\text { Kur mbrëmjet i ndriçonim me zjarr } \\
\text { e prush karboni }\end{array}$ & $\begin{array}{l}\text { E ato ndër ballkone, mbuluar me } \\
\text { vello avujsh trëndafili, kur m'ish i }\end{array}$ \\
$\begin{array}{l}\text { Et les soirs au balcon, voilés de } \\
\text { vapeur roses. ("Le balcon", fq. 44) }\end{array}$ & $\begin{array}{l}\text { Sa i ëmbël qe gjiri yt! Sa e mirë } \\
\text { zemra jote! ("Balkoni”, fq. 35) }\end{array}$ & $\begin{array}{l}\text { ëmbël gjoksi yt! Zemra jote tërë } \\
\text { mirësi! ("Ballkoni", fq. 52) }\end{array}$ \\
\hline $\begin{array}{l}\text { Nous mettrons notre orgueil à } \\
\text { chanter ses louanges! ("Tout } \\
\text { entiere", fq. 52) }\end{array}$ & $\begin{array}{l}\text { Me kreni do të këndojmë lavde } \\
\text { adhurimi. ("Ajo e tëra", fq. 41) }\end{array}$ & $\begin{array}{l}\text { Krenaria jonë i gjunjëzohet duke i } \\
\text { thurrur lavdi. ("Një e tërë", fq. 59) }\end{array}$ \\
\hline
\end{tabular}

From the examples we found that the order of words from the original language to Albanian differs, even in the translation variants in many cases, words are added to make the verse more understandable to the reader, words that are not in the original. In some of the aforementioned examples from a defined structure of the type: Subject-predicative-object, in translations into Albanian this sequence is either reversed, or there are verses that start directly with the verb, with the object or other second limbs of the Albanian language. These instances of such embedded constructions often become a challenge for the interpreter because their behavior in another language is too difficult, especially difficult to maintain the meaning of the verse, but also the whole contents of a certain poetry. Nida asserts: "that translation is closely related to the problem of language, meaning, and equivalence”. (Nida, A. 1964) Interpreters that have faced such challenges, in most cases have removed, or added a shifted word, when compared to certain expressions of the original.

\subsection{Loss / change of grammatically unrelated words in verse}

In addition to the limbs, the main and the second of the sentence, in the composition of this include other words or phrases. Such words and phrases come up with different constructions, with functional values and changed 
features. In the syntax they are distinguished: a. Interjections

\section{b. Word or intermediate phrases ${ }^{1}$}

The reason we chose grammatically unrelated words in sentences, in our case in the verse, is because these kinds of words have a significant role in poetry, as in the construction of the verse, also carry a certain stylistic role, rhyme, metric, etc. Umberto Eco in the translation book "Të thuash gati të njëjtën gjë" emphasizes that: "Salience of the non linguistic substance is key to the lecture with a poetic function". (Eco, 2006). Poetry is not just a word or just a metric. It is speech music. Another reason is because of the original and the variants in Albanian we will present exactly the losses and the changes that have been made to these words, which in our opinion are a separate challenge for the interpreter, these types of words often suffer the losses, the most common variations in the processes of translation. Each of the types in themselves holds different traits and has its own unique role in a sentence. In the following comparative table between speech types, which affect heavily in poetry, the intonational effects that give it, express feelings, reactions, feelings being unconnected syntactically with the other limbs of the verse.

5.3.1 Interjections

Table 3. Translation of interjections

\begin{tabular}{|c|c|c|}
\hline Ch. Baudelaire & M. Raifi & D. Thomollari \\
\hline $\begin{array}{l}\text { Ah! que n'ai-je mis bas tout un } \\
\text { noeud de vipéres. ("Benediction", } \\
\text { fq. } 2\end{array}$ & $\begin{array}{l}\text { Pse nuk solla një bylyk } \\
\text { gjarpërinj, } \\
\text { ("Bekimi", fq. 7) }\end{array}$ & $\begin{array}{l}\text { Ah, një droçkë nepërkash si nuk linda } \\
\text { më mirë. ("Bekim", fq. 21) }\end{array}$ \\
\hline $\begin{array}{l}\text { Dis-le, belle sorciére, oh! Dis, si tu } \\
\text { le sais. ("L'irreparable", fq. 64) }\end{array}$ & Untranslated poetry & $\begin{array}{l}\text { Engjëll plot shëndet, ethet e } \\
\text { t’lënguarve a i njeh. ("Prapsueshmëri", } \\
\text { fq. } 60 \text { ) }\end{array}$ \\
\hline
\end{tabular}

5.3.2 Word or intermediate phrases

Table 4. Translation of word or intermediate phrases

\begin{tabular}{|l|l|l|}
\hline Ch. Baudelaire & M. Raifi & D. Thomollari \\
\hline $\begin{array}{l}\text { Demain, aprés-demain et toujours!- } \\
\text { comme nous. ("Le masque", fq. 31) }\end{array}$ & $\begin{array}{l}\text { Si për në, për të gjithë, si } \\
\text { nesër e pasnesër. ("Maska", } \\
\text { fq. 24) }\end{array}$ & $\begin{array}{l}\text { Nesër, pasnesër e përgjithmonë! - } \\
\text { njësoj si ne. ("Maska", fq. 39) }\end{array}$ \\
\hline $\begin{array}{l}\text { Toujours, toujours en vrain, l'etre aux } \\
\text { ailes de gaze! ("L'irreparable", fq. 66) }\end{array}$ & Untranslated poetry & $\begin{array}{l}\text { Engjëll plot lumturi, plot gaz e plot } \\
\text { dritë? ("Prapsueshmëri", fq. 61) }\end{array}$ \\
\hline
\end{tabular}

\subsection{The phenomenon of homogeneity as a challenge for the interpreter}

In the grammar of the Albanian language, but also in French too, the phenomenon of homogeneity is defined as such: "Homogeneous limbs are called limbs that fulfill the same syntactic functions, are in the same relationships with the same limb and in meaningful coordination relationships between them, united with asynchronous and coordinating links. "2 One of the more common issues that we will be dealing with and for good reason are, firstly because the author we have chosen is distinguished for his intense use of homogeneous limbs in his poetry, which in a poem necessarily carry a stylistic and emotional function.

Secondly, we think that an interpreter faces difficulties. To have homogeneity, words must be in equality used and have the same syntax functions. Thus, the translation of these limbs becomes a challenge, because the translators in most cases do not convey this phenomenon in their variants, and also despite the fact that we may have one word after the other, they are not homogeneous to one another. These changes and losses mostly affect poetry, especially this author, I emphasize this fact because Baudelaire is distinguished for a very special syntax, so his poetry has suffered profound losses in Albanian translations. We must also say that we have various changes from the variant to the variant, not just between the variants and the original.

The following table will show this phenomenon and the changes that it is experiencing.

\footnotetext{
${ }^{1}$ Akademia e shkencave të Shqipërisë,2002. Instituti i gjuhësisë dhe letërsisë. “Gramatika e gjuhës shqipe 2”, , Tiranë, fq.356

${ }^{2}$ Akademia e shkencave të Shqipërisë,2002. Instituti i gjuhësisë dhe letërsisë.“Gramatika e gjuhës shqipe 2”, , Tiranë, fq. 298
} 
Table 5. Translation of the homogeneous limbs

\begin{tabular}{|c|c|c|}
\hline Ch. Baudelaire & M. Raifi & D. Thomollari \\
\hline $\begin{array}{l}\text { O serments, o parfums, o baisers } \\
\text { infinis! ("Le balcon", fq. 45) }\end{array}$ & $\begin{array}{l}\text { O betime, erëra, të puthura } \\
\text { t'paskaj! ("Balkoni”, fq. 36) }\end{array}$ & $\begin{array}{l}\text { O premtime, o parfume, o lumë } \\
\text { puthjesh i pashteruar! ("Ballkoni”, } \\
\text { fq. 53) }\end{array}$ \\
\hline $\begin{array}{l}\text { La sottise, l'erreur, le péché, la } \\
\text { lésine. ("Au lecteur", fq. } 1\end{array}$ & $\begin{array}{l}\text { Mëkati, mashtrimi dhe koprracia e } \\
\text { ndyrë. ("Lexuesit", fq. 5) }\end{array}$ & $\begin{array}{l}\text { Budallallëku dhe kurnacëria, } \\
\text { mëkati dhe gabimi. ("Lexuesit", fq. } \\
\text { 19) }\end{array}$ \\
\hline $\begin{array}{l}\text { Ses parfums, ses chansons et ses } \\
\text { doces chaleurs! } \\
\text { ("Correspondances", fq. } 18\end{array}$ & $\begin{array}{l}\text { Parfumet, këngët dhe ngrohtësinë } \\
\text { ëmbëlake! ("Korrespondimet", fq. } \\
\text { 13) }\end{array}$ & $\begin{array}{l}\text { Parfumet e saj, këngët dhe të } \\
\text { ëmblën ngrohtësi. } \\
\text { (“Korrespondenca, fq. 27) }\end{array}$ \\
\hline
\end{tabular}

In the examples above, we see changes not only between the variants and the original, but also with the variants of each other, these changes affect the structure of poetry, (some words or verses are not translated at all), but also in its content and meaning. The phenomena of homogeneity is sometimes achieved in translations into Albanian and sometimes not. This is because words often change from language to language, so the connotation of the word, causes this phenomenon to have difficulty translating it into another language.

\subsection{The total losses that have occurred in poetry}

As the term itself suggests, total losses refer to the loss of language source code texts and show that parts of the original text are removed and create difficulties in connecting to the whole of the other parts of the work in order to have coherence. These losses relate to verbal figurative signs and expressions that are closely related to culture. In this regard, they are unique to the source text and consequently have no equivalence in the translation culture. We think that complete losses during the translation of literary works occur for two main reasons: the cultural distance between the two languages, and as we have mentioned in the above chapters, less similarities between the two languages make the transmission of ideas linguistically and culturally more difficult. The other reason may be the incomplete knowledge of the interpreter on cultural issues of source language. Thus, we notice these losses in idioms, proverbs, or in those untranslated parts that have cultural content in their content and constitute a meaning for the work as a whole.

Below we present some examples where we have complete losses:

Table 6. The losses of the "Correspondace's" poem

\begin{tabular}{|l|l|l|}
\hline \multicolumn{1}{|c|}{ Ch. Baudelaire } & M. Raifi & D. Thomollari \\
\hline $\begin{array}{l}\text { J'aime le souvenir de ces epoques } \\
\text { nues..("Correspondaces", fq. 18) }\end{array}$ & $\begin{array}{l}\text { I kujtoj me mall kohët lakuriqe. } \\
\text { ("Korrespondenca”, fq. 12) }\end{array}$ & $\begin{array}{l}\text { Untranslated the second part of the } \\
\text { poetry. }\end{array}$ \\
\hline
\end{tabular}

The poem taken in the example is relatively long, is a poem divided into parts. In both Albanian variants we encounter differences. Translator M. Raifi does a complete translation of poetry, while translator D. Thomollari translates only the first part of it. So we have a complete loss of a part of the poetry.

Table 7. The losses of the verses and strophes

\begin{tabular}{|l|l|l|}
\hline Ch. Baudelaire & M. Raifi & D. Thomollari \\
\hline $\begin{array}{l}\text { De Satan ou de Dieu, qu'importe? } \\
\begin{array}{l}\text { Ange ou Siréne.... ("Hymne a la } \\
\text { béaute”, fq. 32) }\end{array}\end{array}$ & $\begin{array}{l}\text { Seventh strophe- untranslated } \\
\text { ("Himn për bukurinë", fq. 24) }\end{array}$ & $\begin{array}{l}\text { S'ka rënëdësi je Djall apo Zot! Ëngjëll } \\
\text { a Sirenë të jesh... (“Himn Bukurisë", } \\
\text { fq. 39) }\end{array}$ \\
\hline $\begin{array}{l}\text { Rembrandt, triste hospital tout rempli } \\
\text { de murmuris. (“Les phares, fq. 20) }\end{array}$ & Untranslated verse & $\begin{array}{l}\text { Rembrandt, spital i trishtuar zërash të } \\
\text { brishtë. ("Fanarët", fq. 28) }\end{array}$ \\
\hline
\end{tabular}

In these examples, the loss occurs mainly within verse and strophes. In the first example we have the loss of the last verse of poetry. Poetry consists of seven strophes, while the translator has selected with his full awareness to bring it with six strophes. As for the second example, we are dealing with a range of poetry that is bypassed by translators. The fullness of a poem, even a lack of a verse or a word, seriously damages poetry, not to convey the state of the situation with the same feelings and emotions as in the original text.

Table 8. The total losses

\begin{tabular}{|l|l|l|}
\hline Ch. Baudelaire & M. Raifi & D. Thomollari \\
\hline O cerveaux enfantins! ("La mort", fq. 161) & Untranslated & Untranslated \\
\hline
\end{tabular}

In the aforementioned example, the author's call at the end of poetry has not been translated into Albanian textbooks. The non-translation of this call, which in fact constitutes the most emotional sense of poetry and at the same time carries its essence, seriously damages the speaker's and author's attitude at the same time, so that poem does not convey to the reader those effects that he has in the original. So, we have the case of free translators who according to E. Tupe: "Go as far as they change, enriching in most cases the thoughts and ideas of the author, but in keeping with his style”.(Tupja, E. 2006). 
Referring to the "The Flowers of Evil" volume, we will notice that we have too deep volume losses. Many poems, not just verses, but full poems, are not translated into Albanian. The original work has a construct that is well-liked by the author, every part of it divided into chapters and sub-chapters is an issue for it, because if we refer to the title bearing the "Flowers of Evil" works, each poem is a separate flower and within this seemingly beautiful flower, there is a great evil. To convey the reader to this oxymoron, the author himself has made a special structure of work and poetry, which in Albanian texts is missing. In a definition of poetry given by Gjergj Zheji: "Poetry is seen as a concentrated form, compressed to the maximum emotional speech; precisely for this, every word, every sound, every pause and everything else in it gains a certain coloration”. (Zheji, Gj. 1988). For this reason, to remain as faithful as possible and as closely as possible to the source text, translators should avoid as much as possible the omissions or losses that carry cultural information and primary information about the work as a whole.

\section{Conclusion}

In our paper titled "The challenges of adapting syntactic constructions to the translation of the poem of Charles Baudelaire", we discussed and analyzed various issues related to poetry, translators' challenges to bring in a poem of this author in Albanian. We also concentrated on the problems of literary translation, mainly poetical and the differences between the languages in the sentence plane.

The first part is, in essence, theoretical, which examines various translation problems over the years. It was initially evidenced that there was still a difficult construction of a unitary translation theory, based on scientific foundations. It should also be added that since each language has its own form of structure and therefore there is no complete line between the two languages, the same meaning can be expressed in another language, in a very different grammatical and lexical form. Translation of poetry is considered the most difficult and has been the subject of a broad discussion, where most of the discussions consist of theoretical issues regarding the possibility of translation. J. Holmes notes that "The main problem faced by a translator of a poem, is that he in some way or another must "displacement" the original poetry not only into another linguistic context but, but, unquestionably, "displacement" will happen in another literary context or another social-cultural situation"." The relationship between theory and practice in translating poetry has always been problematic. There are few theories that can provide explanations about the difficulties encountered by current practice, and the perinates that an interpreter should have. The biggest changes and challenges are encountered in language and syntax adjustments, where even the biggest losses occur in case of translation from one language into another. As a conclusion of this issue we quote E. Tupen "translation is and should be a love act, the literary translator should love the book, in the form and content, the only way to try to do everything in its power, especially the heart to translate it best." (Tupja, E. 2008) In this sense, the French writer, critic and French translator Valery Larbaud has the right to say: "Tell me who translates, to tell you who you are".

In this context, we put forward the thoughts and theories of the most renowned theoreticians in the field of translation such as Peter Newmark, Umberto Eco, Edmond Tupja, Eugene Nida, and others. In order to point out whether these theorists had consistency or different perspectives in their attitudes related to translation aspects.

We also addressed the historical-cultural aspect of Charles Baudelaire and his work. Recognizing the author's life and work as well as the historical and cultural factors that influenced him, we came to the conclusion that these factors directly affect the work and difficulty of the author's behavior in another language. We explored the language of this author, his linguistic and syntax aspects, and highlighted the degree of change of his poetry in different translations, but especially in Albanian. To concretize this fact, we analyzed an example given by Umberto Eco, who compares a Baudelaire's poem with its Italian variant, highlighting the numerous linguistic and semantic losses. In this framework, we also analyzed the poem "The Albatross", comparing it to its three variants in Albanian, the variant of I. Kadare, M. Raif. D. Thomollar and concluded that Kadare's translation stands closer to the original and retains more of the syntax of the author's language.

In the second part we focused on the two language codes, Albanian and French, in the context of syntactic constructions, and of the syntax of the sentence. The sentence has definitions in different planes and sketches. E. Benveniste, a french researcher makes the sentence a discursive definition. Among other things, he regards sentence as a speech unit, which can express categorizations, questions, thoughts, feelings, based on some syntactic and grammatical rules. Thus, the sentence expresses the speaker's position depending on the different situations, so the sentence has a publishing function, which distinguishes it from other language units.

We addressed several different issues and argued that the languages in this grammar field differ from one another. We started this chapter with a general look at the sentence between the two grammars and concluded that despite the different forms, the content of this definition and what we call the sentence, remains the same. In the "Grammar of the Albanian Language", the sentence is conceived as a basic unit of lecture, gained on the basis of Albanian language laws, the ties and relationships between words and limbs to express feelings,

\footnotetext{
${ }^{1}$ Holmes, J. S.1994,” Translated Papers on Literary Translation and Translation Studies”, Amsterdam-Atlanta: Rodopi
} 
thoughts, desires, and other forms of thinking. ( AshSh. 2002)

In the "Grammar of the French language" the sentence is, above all, a sequence of words spoken by each subject, but not only, it is able to be reproduced and interpreted, it is intuitive but has its rules and limits. (Girardet, J. P. 2002) We further dealt with the order of words in the sentence and highlighted the great differences between languages, French with an entrenched order, and Albanian with a free order. Further on during this section, we also discussed the changes encountered in constructing questionable and obscure sentences. At the end of this section we have considered some special constructions of the French language. According to Grammaire methodique du française: "There are some words that accompany each phrase in French, (which are almost never used in Albanian), words such as ce / c'est and il y a"l. So, we have come to the conclusion that every language carries some such constructions that belong to that language and at the moment of translation these types of constructions are difficult to translate because they lose the full meaning which characterizes it.

The third part, which we can say is the most important head of this paper, for the fact that it deals with the linguistic analysis of the work, the translation gains that Mensur Raifi and Dritan Thomollari have chosen to bring from French to Albanian. We have addressed several issues about the changes that have undergone syntactic constructions. Unlike French, the order of limbs in sentences in Albanian is not generally embedded. According to M. Çeliku: "There is a common sentence order, that it can change without substantially altering the syntax, most of the time with changes in syntax and stylistic colors for various reasons". (Çeliku, M. 2008) We note the changes that have come to the subject, which originally starts the verse, while in the translations into Albanian it loses, or in its place we have the right / oblique opponent or the other second limb. We also encounter variations between variants in Albanian, but it should be said that M. Raif's translation is more accurate, while maintaining some important specifics of syntactic constructs. Another important thing to note is the order of words in the verse. Poetry in the original despite being poetry and in such a literary genre for various metric and stylistic causes become deviations of syntactic constructions, while Baudelaire, in most of his poems has maintained the rigid order of words in verses. So, we have a structure of the Subject + Predicate + Object type, which in the variant in Albanian is not preserved since the Albanian language has a free order of words in sentences.

In the course of this approach, we also dealt with the changes that have been made to grammatically unrelated words in the verses. The reason we chose grammatically unrelated words in sentences is, in our case, the fact that these types of poetry have a significant role, such as constructing the string, also carry a certain stylistic metric role. Another reason is because, for our opinion, there is a challenge for an interpreter, these types of words often suffer losses, the most varied changes in translation processes. Another issue to be considered is the phenomenon of homogeneity. According to the Grammar of the Albanian language: "Homogeneous limbs are called those limbs that fulfill the same syntactic functions, are in the same relationships with the same limb and in meaningful coordination reports between them, by joining with coordinating and asymmetric relations." (AshSh. 2002) The selected work is distinguished for such a feature, which is very important, both linguistically and stylistically because it gives the effect of the string. To have homogeneity, words must be in equality reports and have the same syntax functions. Thus the translation of these limbs becomes a challenge, because the translators in most cases do not convey this phenomenon in their variants, and also despite the fact that we may have one word after the other, they are not homogeneous to one another. It should be said that in this aspect closer to the original again results the translation of Mensur Raifi. Finally, we have dealt with the total loss of poetry. Thus, we notice these losses in idioms, proverbs, or in those untranslated parts that have cultural undertones in their content and constitute a meaning for the work as a whole. If we look at the poetic volume in its entirety, there are many untranslated poems, numerous verses and strophes lost, which directly affect the structure of the work that is well liked by the author. U. Buçpapaj think that: "In poetry, perfection is not only achieved by choosing words and figurative language, but also through the creation of rhythm, rhyme, metrics, expressions, and specific structures, which may not coincide with those of daily language". (Buçpapaj, U. 2009) The structure itself constitutes the whole significance of Baudelaire's poetry. To conclude, we can say that in the process of dealing with some important issues of translation theory in general, the differences between two syntactic languages, the translation of the linguistic and syntax elements of poetry from the French into Albanian language. We hope to shed light on the above-mentioned issues. We also hope that this work has accomplished its purpose and serves as an incentive for further studies in the context of Albanian translation studies, especially of linguistic and literary studies, for this very important author of French and world literature as well.

\section{References}

Aggeler, W. (1954). The flowers of Evil, Fresno. CA: Academy Library Guild

\footnotetext{
${ }^{1}$ Martin, R. Pellat,J. Rioul,R. (2014). Grammaire methodique du française. Paris: Press Universitares de France.
} 
Agalliu, T. (1990). Mannuel de grammaire française. Tiranë: SHBLSH.

AshSH. (2002). Gramatika e gjuhës shqipe 2. Tiranë: SHBLU.

AshSh. (2002). Gramatika e gjuhës shqipe I. Tiranë: Botim i Akademisë së shkencave.

Baudelaire, C. (1951). Les fleurs du mal. Paris: Editions du Dauphin.

Baudiffles, S. (2006). Les grands fondateurs de la poesie moderne. Paris: France Loisirs.

Benveniste, E. (2011). A la recherche de la longue de Baudelaire. Paris: Lambert-Lucas.

Buçpapaj, U. (2009). Përkthimi poetik. Tiranë: Botim i akteve të konferencës shkencore ndërkombëtare,UT,

Çeliku, M. (2008). Tekst ushtrimesh për sintaksën standard. Tiranë: ILAR.

Çeliku, M. (2012). Sintaksë e gjuhës shqipe ( Përbërësit sintaksorë). Tiranë: ILAR.

De Saussure, F. (2002). Kurs i gjuhësisë së përgjithshme. Tiranë: Dituria.

Dolet, E. (1540). How to translate well from one language into another. France.

Domi, M. (1969). Gramatika e gjuhës shqipe, Sintaksa. Prishtinë: Enti i teksteve dhe i mjeteve.

Fairclough, N. (2006). Language and Globalization. London, Routledge: Taylor \& Francis groupe.

FGJSH. (1980). Fjalor i guhës së sotme shqipe. Tiranë: Akademia e shkencave.

Frost, W. (1969). Dryden and the art of translation. New Haven CON: Yale Universsity Press.

Girardet, J. P. (2002). Campus, methode de française. Paris: CLE.

Holmes, J. (1994). Translated papers on literary translation and traslation studies. Amsterdam-Atlanta: Rodopi. Jakobson, R. (1966). On linguistic, Aspects of translation. Brower, R.A.: Oxford Universsity Press.

John, C. (1965). A linguistic theory of translation. London: Universsity Press.

Kadare, I. (1990). Ftesë në studio. Tiranë: Naim Frashëri.

Lattimore, R. (1966). Practical notes on Translating Poetry. London: Universsity Press.

Lefevere, A. (1975). Translating Poetry. Amsterdam - Assen: Seven strategies and blueprint.

Leuven-zwart, K. (1989). Translation and original, ( Similiarities and Dissimiliarities). Target 1.

Martin, R. Pellat, J. Rioul, R. (2014). Grammaire methodique du française. Paris: Press Universitares de France.

Memushaj, R. (2008). Hyrje në gjuhësi. Tiranë: Botimet Toena.

Nida, E. (1964). Toward a Science of Transaltion. Netherland: Bill Academic Publishers.

Newmark, P. (1991). About translation. Multilingual Matters.

Newmark, P. (1988). A textbook of translation. Prentice Hall.

Përnaska, R. (2015). Gjuhësi...Gjuhësore. Tiranë: Maluka.

Plasari, A. (1990). Letërsia dhe Muret. Tiranë: Shkrimtari dhe Koha.

Raifi, M. (1991). Mërzitje dhe Ideal. Prishtinë: Rilindja.

Richardson J. (1994). Baudelaire. New York: St. Martin's Press

Robins, R. (2007). Histori e gjuhësisë. Tiranë: Dituria.

Rrokaj, S. (2010). Filozofi e Gjuhës. Tiranë: Arbëria.

Rrota, J. (2005). Sintaksi i Shqipes. Shkodër: Botimet Françeskane.

Rushiti, R. (n.d.). Leksione të shkurtuara të sintaksës shqipe.

Shqipërisë, A. (e.) (2002). Fjalor i shqipes së sotme. Tiranë: Botimet Toena.

Thomai, J. Haxhillazi, P. Shehu, H. Memisha,V. Goga, A. (2006). FGJSH. Tiranë: Akademia e shkencave.

Thomollari, D. (2004). Lulet e së keqes. Tiranë: PLEJAD.

Tufa, A. (2008). Mistika e origjinalit. Tiranë: Tezë doktorature.

Tupja, E. (2006). Keshilla nje perkthyesi te ri. Tiranë: Dituria.

Tupja, E. (2003). Pro Translatore. Tiranë: Ombra OVG

Umberto, E. (2006). Të thuash gati të njëjtën gjë, ( Përvoja përkthimi ). Tiranë: Dituria.

Vataj, A. (2012). Sh.Bodler, heretiku që u dogj në ferrin e anatemës. Tiranë: Gazeta Tema.

Waldrop, R. (1979). The joy of the demiurge. London: Universsity Press.

Xhuvani, A. (1938). Njohunit e para të sintaksës shqipe 1. Tiranë.

Ymeri, E. (2015). Përkthimi, një histori pasioni. Tiranë: OMSCA-1

Zheji, G. (1988). Bazat e vargëzimit shqiptar. Tiranë: Naim Frashëri. 